\title{
Sustainability science: The emerging research program
}

\author{
William C. Clark* and Nancy M. Dickson \\ John F. Kennedy School of Government, Harvard University, Cambridge, MA 02138
}

Communicated by Susan Hanson, Clark University, Worcester, MA, March 7, 2003 (received for review February 25, 2003)

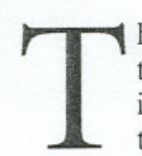

he last decade has witnessed the emergence of an array of increasingly vibrant movements to harness science and technology (S\&T) in the quest for a transition toward sustainability. These movements take as their point of departure a widely shared view that the challenge of sustainable development is the reconciliation of society's development goals with the planet's environmental limits over the long term. In seeking to help meet this sustainability challenge, the multiple movements to harness science and technology for sustainability focus on the dynamic interactions between nature and society, with equal attention to how social change shapes the environment and how environmental change shapes society. These movements seek to address the essential complexity of those interactions, recognizing that understanding the individual components of nature-society systems provides insufficient understanding about the behavior of the systems themselves. They are problem-driven, with the goal of creating and applying knowledge in support of decision making for sustainable development. Finally, they are grounded in the belief that for such knowledge to be truly useful it generally needs to be "coproduced" through close collaboration between scholars and practitioners. The research and applications program that has begun to emerge from these movements has been called "sustainability science" $\dagger$ by the National Research Council (1). This Special Feature highlights this emerging program and some of the new results it is beginning to produce.

The need for sustainable development initiatives to mobilize appropriate science and technology has long been recognized. Early research on sustainable yield management of renewable resources provided the foundation for the International Union for the Conservation of Nature's seminal World Conservation Strategy, published in 1980 . The case for making appropriate research and development (R\&D) an integral component of sustainable development strategies was broadened by a number of international scientific organizations during the mid-1980s, promoted by the Brundtland Commission's report Our Common Future in 1987, and enshrined in the Agenda 21 action plan that emerged from the United Nations Conference on Environment and Development in 1992. Over the succeeding decade, the discussion of how S\&T could contribute more effectively to sustainability intensified, involving numerous researchers, practitioners, scientific academies, and development organizations from around the world (2). By the time of the World Summit on Sustainable Development, held in Johannesburg in 2002, a broadly based consensus had begun to take shape on the most important ways in which S\&T has already contributed to sustainability, on what new R\&D is most important, and on what stands in the way of getting it done (3-8).

\section{Sustainability science focuses on the dynamic interactions between nature and society.}

Many of the most valuable contributions of S\&T to sustainable development predate the term itself. These range from the "mundane technologies" that have improved delivery of basic needs for sanitation and cooking (9), through the yield-enhancing, land-saving accomplishments of the international agricultural research system (10), to the fundamental scholarship of geographers and anthropologists on nature-society interactions (11). In more recent times, a host of R\&D efforts explicitly aimed at promoting sustainability have been launched. These extend from a rich tradition of work on energy systems (12) and ecosystem resilience (13) to new initiatives in industrial ecology (14) and earth system complexity (15). A feel for the breadth and scope of relevant R\&D now underway around the world is suggested by the rapidly growing list of entries on the virtual "Forum on Science and Technology for Sustainability" (16).

However, much remains to be done. Perhaps the strongest message to emerge from dialogues induced by the Johannesburg Summit was that the research community needs to complement its historic role in identifying problems of sustainability with a greater willingness to join with the development and other communities to work on practical solutions to those problems. This means bringing our S\&T to bear on the highest-priority goals of a sustainability transition, with those goals defined not by scientists alone but rather through a dialogue between scientists and the people engaged in the practice of "meeting human needs while conserving the earth's life support systems and reducing hunger and poverty" (17). At the international level, the Johannesburg Summit, building on the United Nations Millennium Declaration, has defined these priorities in terms of the so-called "WEHAB" targets for water, energy, health, agriculture, and biodiversity $(18,19)$. A more systematic study of internationally sanctioned goals and targets for a sustainability transition, together with an evaluation of the state of reporting and assessment on progress in attaining those goals, is provided by Parris and Kates in their contribution to this Special Feature (20). As important as this international consensus on goals and targets may be for targeting problem-driven research in support of a sustainability transition, however, it is not sufficient. A joint workshop held by the International Council for Sciences, the Third World Academy of Science, and the Initiative on Science and Technology for Sustainability concluded that "agenda setting at the global, continental, and even national scale will miss a lot of the most important needs.... The transcendent challenge is to help promote the relatively 'local' (place- or enterprise-based) dialogues from which meaningful priorities can emerge, and to put in place the local support systems that will allow those priorities to be implemented" (21). Where such systems exist, the production of usable, place-

\footnotetext{
Abbreviations: S\&T, science and technology; R\&D, research and development.

*To whom correspondence should be addressed. E-mail: william_clark@harvard.edu.

"The term "sustainability science" has been controversial, connoting to some a mature discipline with shared conceptual and theoretical components that most certainly does not exist. One alternative descriptor is "the science of sustainability," which conveys the notion of multiple sciences addressing a common theme. Our use of "sustainability science," like that of the National Research Council, carries this last meaning.
} 
based knowledge for promoting sustainability has been impressive indeed.

The commitment of sustainability science to problem-driven agenda setting does not mean that it has been confined to "applied" research. Indeed, pursuit of practical solutions to the pressing challenges of sustainability has driven the field to tackle an array of fundamental questions. The Friibergh Workshop on Sustainability Science (5) identified a half-dozen such core conceptual questions that have been further developed through the virtual Forum on Science and Technology for Sustainability (22) and are beginning to appear in the context of emerging agendas in other more established fields, such as global environmental change (23). Examples of the new sorts of research now beginning to emerge on several of those core questions are reported elsewhere in this Special Feature: Kates and Parris (24) on "How are long-term trends in environment and development reshaping nature-society interactions in ways relevant to sustainability"; Turner et al. $(25,26)$ on "What determines the vulnerability or resilience of the naturesociety systems in particular kinds of places and for particular types of ecosystems and human livelihoods?"; and Cash et al. (27) on "How can today's relatively independent activities of research planning, observation, assessment, and decision support be better integrated into systems for adaptive management and societal learning?" The sustainability science program is also beginning to address a range of fundamental observational and methodological challenges. For example, H. J. Schellnhuber and his colleagues at the Potsdam Institute for Climate Impact Research have developed innovative new answers to the question

1. National Research Council (1999) Our Common Journey (Natl. Acad. Press, Washington, DC).

2. Clark, W. C., Lebel, L., Gallopin, G., Jaeger, J., Mabogunje, A., Dowdeswell, E., Hassan, M., Juma, C., Kates, R., Corell, R., et al. (2002) in Science and Technology for Sustainable Development (Int. Council for Science, Paris), pp. 12-29.

3. InterAcademy Panel on International Issues (2000) Transition to Sustainability in the 21st Century (InterAcad. Panel Int. Issues, Toyko), http:// interacademies.net/intracad/tokyo2000.nsf/all/ home.

4. International Institute for Environment and Development (2002) Research Partnerships for Sustainable Development (Int. Inst. Environ. Dev., Cambridge, U.K.), www.iied.org/wssd/pdf/ 31_RSPD_Cambridge_Report.pdf.

5. Kates, R. W., Clark, W. C., Corell, R., Hall, J. M., Jaeger, C. C., Lowe, I., McCarthy, J. J., Schellnhuber, H. J., Bolin, B., Dickson, N. M., et al. (2001) Science 292, 641-642.
"How can the dynamic interactions between nature and society-including lags and inertia-be better incorporated in emerging models and conceptualizations that integrate the Earth system, human development, and sustainability?" (28). Wolfgang Lucht, writing in the IHDP Update, summarizes current work on answering "How can today's operational systems for monitoring and reporting on environmental and social conditions be integrated or extended to provide more useful guidance for efforts to navigate a transition toward sustainability?" (29). And a number of groups are calling for reexamination of national and international social account measures to include sustainability considerations.

Activities to advance the sustainability science program are moving forward on a number of fronts and at scales from the global to the local. One of the more up-to-date lists of programs and projects is maintained on the Forum on Science and Technology for Sustainability (30). As an indication of the range of activities underway internationally, the International Council for Science, Third World Academy of Sciences, Initiative on Science and Technology for Sustainability, and other organizations have formed a Consortium for promoting a coordinated international program of research, capacity building, and applications. The Earth System Science

Partnership of the Global Environmental Change Programmes has launched a series of "Joint Projects on Sustainability" focused on problems of food security, water, and carbon management. An increasing number of international science assessments for environmental protection (e.g., the Intergovernmental Panel on Climate Change and Millennium Ecosystem Assessments) are in-

6. Larigauderie, A. (2002) Global Change Newsletter 50, 37-38, 51, www.igbp.kva.se/uploads/11_ESSP. pdf.

7. International Council for Science (2002) Report of the Scientific and Technological Community to the World Summit on Sustainable Development (Int. Council for Science, Paris), www.icsu.org/ Library/WSSD-Rep/Vol1.pdf.

8. International Council for Science (2002) Science and Technology for Sustainable Development (Int. Council for Science, Paris), www.icsu.org/Library/ WSSD-Rep/Vol9.pdf.

9. Dove, M. R. \& Kammen, D. M. (1997) Environment 39, 10-15, 38-41.

10. Ruttan, V. W. (2001) Technology, Growth, and Development (Oxford Univ. Press, New York).

11. Glacken, C. (1967) Traces on the Rhodian Shore (Univ. Calif. Press, Berkeley).

12. Haefele, W. \& The Energy Systems Program Group of the International Institute for Applied Systems Analysis (1981) Energy in a Finite World (Balinger, Cambridge, U.K.) corporating sustainability concerns. And a rapidly expanding set of multistakeholder "Partnerships for Sustainable Development" are developing in the wake of the Johannesburg Summit (31). An even greater variety of S\&Tbased efforts are underway at the local, regional, and national levels around the world. The research products of some of these efforts are beginning to appear in the published literature, although many of the relatively local results remain largely unknown beyond their places of origin and application.

Sustainability science is not yet an autonomous field or discipline, but rather a vibrant arena that is bringing together scholarship and practice, global and local perspectives from north and south, and disciplines across the natural and social sciences, engineering, and medicine. Its scope of core questions, criteria for quality control, and membership are consequently in substantial flux and may be expected to remain so for some time. Nonetheless, as the papers included in this Special Feature are meant to suggest, something different is surely "in the air," something that is intellectually exciting, practically compelling, and might as well be called "sustainability science."

The set of papers introduced here is dedicated to Jeanne X. Kasperson, a longstanding scholar of human-environment studies, especially those dealing with risk, hazards, and vulnerability. Jeanne was a member of the Research and Assessment Systems for Sustainability Program that produced this set and an author of the paper on vulnerability. Jeanne passed away unexpectedly in 2002 . This work was supported by a grant from the National Science Foundation (BCS-0004236), with contributions from the National Oceanic and Atmospheric Administration's Office of Global Programs for the Research and Assessment Systems for Sustainability Program (http://sust.harvard.edu).

13. Holling, C. S. (1973) Annu. Rev. Ecol. Syst. 4, $1-23$.

14. National Academy of Engineering (1997) The Industrial Green Game (Natl. Acad. Press, Washington, DC).

15. National Science Foundation Advisory Committee on Environmental Research and Education (2003) Complex Environmental Systems (Natl. Sci. Found., Washington, DC).

16. Initiative on Science and Technology for Sustainability (2003) Forum on Science and Technology for Sustainability, http://sustainabilityscience.org.

17. National Research Council (1999) Our Common Journey (Natl. Acad. Press, Washington, DC).

18. United Nations World Summit on Sustainable Development (2002) WEHAB Framework Papers, www.johannesburgsummit.org/html/documents/ wehab_papers.html.

19. United Nations General Assembly (2000) United Nations Millennium Declaration (United Nations, New York), A/RES/55/2. 
20. Parris, T. M. \& Kates, R. W. (2003) Proc. Natl. Acad. Sci. USA 100, 8068-8073.

21. International Council for Science (2002) in Science and Technology for Sustainable Development (Int Council for Science, Paris), www.icsu.org/Library/ WSSD-Rep/Vol9.pdf, p. 9 .

22. Initiative on Science and Technology for Sustain ability (2003) Core Questions of Science and Technology for Sustainability, http://sustainabilityscience.org/questions/intro.htm.

23. Sahagian, D. \& Schellnhuber, H. J. (2002) Global Change Newsl. 50, 7-10, www.igbp.kva.se/uploads/ 3_GAIM.pdf.
24. Kates, R. W. \& Parris, T. M. (2003) Proc. Natl. Acad. Sci. USA 100, 8062-8067.

25. Turner, B. L., II, Kasperson, R. E., Matson, P. A McCarthy, J. J., Corell, R. W., Christensen, L., Eckley, N., Kasperson, J. X., Luers, A., Martello, M. L. et al. (2003) Proc. Natl. Acad. Sci. USA 100, 8074-8079.

26. Turner, B. L. II, Matson, P. A., McCarthy, J. J, Corell, R. W., Christensen, L., Eckley, N., Hovelsrud-Broda, G. K, Kasperson, J. X., Kasperson, R. E., Luers, A. al. (2003) Proc. Natl. Acad. Sci. USA 100,8080-8085.

27. Cash, D. W., Clark, W. C., Alcock, F., Dickson, N. M., Eckley, N., Guston, D. H., Jäger, J. \& Mitchell, R. B. (2003) Proc. Natl. Acad Sci. USA $100,8086-8091$.
28. Schellnhuber, H. J. (2003) in Challenges of a Chang ing Earth, eds. Steffen, W., Jaeger, J., Carson, D. \& Bradshaw, C. (Springer, Berlin), pp. 151-156

29. Lucht, W. (2002) IHDP Update 2, 6

30. Initiative on Science and Technology for Sustainability (2003) Forum on Science and Technology for Sustainability: Programs and Institutions (http:// sustainabilityscience.org/links.htm)

31. United Nations World Summit on Sustainable Development (2003) List of Partnerships for Sustainable Development and Summary (www.un. org/esa/sustdev/partnerships/list_partnerships. $\mathrm{htm})$ 


\title{
Long-term trends and a sustainability transition
}

\author{
Robert W. Kates* ${ }^{\dagger}$ and Thomas M. Parris ${ }^{\ddagger}$ \\ *33 Popple Point, Trenton, ME 04605-6000; and ₹ISciences, LLC, 685 Centre Street, Suite 207, Jamaica Plain, MA 02130-2559
}

Communicated by Susan Hanson, Clark University, Worcester, MA, March 7, 2003 (received for review February 25, 2003)

How do long-term global trends affect a transition to sustainability? We emphasize the "multitrend" nature of 10 classes of trends, which makes them complex, contradictory, and often poorly understood. Each class includes trends that make a sustainability transition more feasible as well as trends that make it more difficult. Taken in their entirety, they serve as a checklist for the consideration of global trends that impact place-based sustainability studies.

$\mathbf{S}$ ome long-term trends in nature and society serve as currents along which we can navigate directions toward a 21st century sustainability transition. This transition is seen as one where a stabilizing world population meets its needs and reduces hunger and poverty while maintaining the planet's life support systems and living resources (1). "Bending the curve," accelerating favorable trends, slowing harmful trends, understanding complex trends, and noting changes in direction and inflection that constitute significant departures (2) are among the grand challenges of sustainability science. A core question of sustainability science asks, "How are long-term trends in environment and development, including consumption and population, reshaping nature-society interactions in ways relevant to sustainability?" $(3,4)$.

In 1999, the National Research Council's Board on Sustainable Development (1) reviewed "some major historical trends and transitions that might significantly affect the prospects for sustainability over the next half century" (ref. 1, p. 59). Because one of us (R.W.K.) is lead author of that review, we draw heavily on that analysis, and add material related to peace, security, and globalization. Thus, we describe 10 major classes and 26 long-term global and regional trends that make a sustainability transition more feasible as well as more difficult. We illustrate each with recent long-term data and assay the potential to slow or accelerate the trend to enhance a sustainability transition.

\section{Peace and Security}

War, conflict, crime, and corruption are major threats to a sustainability transition in myriad ways: directly by destroying human lives, capital, infrastructure, and the environment; and indirectly by diverting needed productive resources, increasing exploitation of natural resources, and encouraging "fortress worlds," where personal security dominates concerns for the common good (5). Since 1945 , two major trends are evident.

Increasing Conflict amid Cold War. Over the last 50 years, there has been a steady increase in the incidence of armed conflict worldwide. Characterized as a "cold war," almost 300 armed conflicts $(>500$ fatalities) of international, civil, ethnic, and genocidal violence and warfare occurred. At its peak in 1992, one-third of the countries of the world contained such conflicts (6). Perhaps 25 million people died directly from the violence, exceeding that of World Wars I and II (7), and in 1992 there were $>40$ million refugees and displaced persons (8). Unlike the previous two great wars, warfare between states was rare, and civil, ethnic, and religious conflict dominated, often as proxy battles of the cold war or from a legacy of unresolved colonialism. Barely reflected in such data has been the growing globalization of both terror and crime beyond state borders.

Conflict at a Turning Point? The recent decade began with harbingers of "the coming anarchy" (9) and the "clash of civilizations" (10). Yet there has been a marked downturn in all forms of conflict over the last decade and intense and promising efforts are being made to resolve long-standing conflicts in the Congo, Sri Lanka, and the Sudan. Between 1992 and 1999, the proportion of states experiencing warfare declined from one-third to less than one-fifth (6), although data sets that count only more intense conflicts show less decrease (11). Moreover, a long-term data set covering the period 1816-1997 shows the last half-century as an anomaly of increased violence, and thus we may be evidencing a return to a persistent but lower level of conflict (7). If so, multinational and international efforts to broker resolution of long-standing conflicts, to prevent initiation of new ones, and to address the roots of terror that lie in the great world inequities (12) might accelerate such a favorable trend.

\section{Population, Migration, and Urbanization}

Population numbers, location, and trends help define a sustainability transition by bounding both the numbers of humans whose needs are to be met and the size of the driving force of threats to the planet's life support systems. A global transition from high to low birth and death rates and from rural to urban locations is well underway, and the implied end to population growth offers an upper limit to human needs. Population is also a major driving force for environmentally damaging emissions, impacts, or resource consumption. The impact of urbanization is felt through its "footprint" on land and resource uses and environmental impacts elsewhere $(13,14)$. Since 1950 , major population trends related to a sustainability transition have been as follows.

Slowing and Differential Population Growth. World population is estimated at 6.3 billion today, with an annual growth rate of $1.22 \%$. Growth rates have declined since the peak rate, $\approx 2.2 \%$ per year, that occurred in the early 1960s. The latest United Nation "medium" estimate of global population for 2050 is currently 8.9 billion. This figure is 400 million lower than a similar estimate made in 2000 due to lower projected fertility levels and increased deaths caused by HIV/AIDS. Although all regions of the world show declining fertility without migration, all of the projected growth takes place in developing countries. The population of Africa is projected to grow by 1 billion people even with the evolution of the AIDS/HIV epidemic. At the same time, continued global fertility decline will also lead to increasing aging of the population from $\approx 10 \%$ of the world's population ( $>60$ years) in 2000 to more double that in 2050 (15).

Continuing Rural Migration and Rapid Expansion of Cities. By 2007, for the first time in human history, more people will live and work in the urban centers of the world than in rural areas, a continuation of the movement of people from country to city. The urban proportion of the population is projected to grow to $60 \%$ (2030) with Latin America, North America, Europe, and Oceania already $>70 \%$ urbanized (16). To accommodate $>2$ billion more urban dwellers by 2030 , cities need to expand at a rate equivalent to building $>13$ great cities ( $>5$ million) each year, virtually all in less developed regions of the world.

Pulsating International Migration. International migration has grown slowly at a rate slightly higher than population growth, and $\approx 150$ million people worldwide today are living in a country other than that of their birth. Because international migration is punc-

'To whom correspondence should be addressed. E-mail: rkates@acadia.net. 
tuated by cyclical periods of either economic growth and immigration liberalization or by periods of forced emigration from war, conflict, and political change, the different locations, rapidity, and perception of international migration change more quickly than the slowly growing average.

Meeting the needs of 3 billion more people, housing and employing 2 billion new urban residents, caring for aging populations of industrialized countries, and absorbing the migrants those societies will thus require, while limiting the environmentally damaging impacts of such growth and urbanization, are all major challenges of a sustainability transition. But these may be one-time challenges brought about by the demographic transition. The projected peak population can be reduced by as much as 1 billion people by making contraception available to all who want it and by increasing opportunities for girls and women to have education and jobs (17). The urban expansion also offers new opportunities to replace the current infrastructure and to build anew in an energy- and waterefficient manner (18).

\section{Affluence/Poverty, Well-Being, and Health}

Meeting human needs of a much larger population requires growth in affluence (income and wealth) and its distribution in ways that reduce hunger and poverty. Improved income is only part of improved well-being that is partly captured in such indices as the Human Development Index, which combines a measure of life expectancy and health, education, and income (19). Just as wellbeing is more than income, concepts of distribution of well-being are broader than that of simple income equity and include entitlements and equality. Taken together, goals and targets such as those found in the Millennium Declaration express the range of internationally agreed-on concepts by which well-being might be monitored and the success of a sustainability transition can be evaluated (20). Since 1950, major trends related to a sustainability transition have been as follows.

Growing Affluence and Persistent Poverty. Per capita gross domestic product, a measure of the total economic activity in the world's markets and a standard measure of affluence, has grown $>8$-fold since 1820 (21). All regions of the world except Africa, where growth has stopped recently, show such growth. However, differences between regions persist. Poverty, as estimated by the World Bank, is extensive with $\approx 1.2$ billion $(23 \%$ ) people living on $<\$ 1$ per day and 2.8 billion $(56 \%)$ on $<\$ 2$ per day in 1998. As with similar figures on hunger, the proportion of impoverished people has declined over time, but with population growth, the absolute number has remained surprisingly constant (22).

Growing Income Inequality and Shrinking Entitlement. A well known aphorism states, "a rising tide raises all boats." But the rising tide of average per capita income does not raise the life rafts of the poor and the yachts of the superrich equally. Trends indicate that income inequality has grown over time between countries, within many countries, and perhaps among people, but there are lively differences of opinion as to degree, rates of change, and for a few, even the directions of change $(23,24)$. Over the last half-century, there has been a narrowing of disparities in wealth among rich countries, but inequality has increased between rich and poor countries, with the notable exceptions of those in East and Southeast Asia (25). At the same time, within-country inequality has grown in many rich and poor countries. There have also been changes in entitlements, the bundle of income, natural resources, familial and social connections, and societal assistance that are key determinants of hunger and poverty (26). For much of the last half-century, entitlements grew in centrally planned countries through social or work-related programs of food, education, health, and housing and in all industrialized market-oriented countries through a safety net for citizens. But with the emergence of market-oriented economies in Russia and China and the rising costs of entitlement programs in the industrialized countries, many of these entitlements have shrunk or disappeared. In developing countries, entitlements have also shrunk often as part of International Monetary Fundrecommended structural adjustment programs.

Improved Well-Being and Greater Human Equality. Over the last 50 years, the overall well-being of people has substantially improved. Using the measures of the Human Development Index, life expectancy has been extended $>20$ years since 1950 , adult literacy has risen $>20 \%$ since 1970 , and per capita gross domestic product (purchasing power parity) has more than tripled since 1960 (27, 28). Greater equality is evident in improvements in such indicators as the male-female ratio in primary education, the numbers of people living in countries with democratic or partly democratic regimes, and the growing willingness of the international community to protect civilians from internal conflict, to protect national minorities, and to bring to justice perpetrators of war crimes, genocide, and extreme forms of repression.

Better Health and Shifting Disease. The dramatic increase in life expectancy from 46 to 66 years over the past 50 years reflects reductions in infant and child mortality and morbidity for which immunization, improved water, sanitation, and nutrition have played major roles. But with the extension of life span, a major shift in the nature of disease takes place, one from infectious diseases characteristic of developing countries to the chronic diseases of industrialized countries. Recently, there has been a surprising reemergence of infectious diseases, sometimes dubbed the "third epidemiological transition," such as HIV, tuberculosis, yellow fever, lyme disease, and dengue fever (29). This reemergence is due, in part, to the combined factors of increased global trade and mobility and antimicrobial resistance.

Overall, these trends auger well for a sustainability transition for most of the world's people, but they underline the plight of those that are left in poverty sustained by growing inequality and shrinking entitlements or that are denied the opportunity of life from the pandemic of AIDS and shifting disease patterns. Yet it is the great increases in wealth of the last 50 years and the projected increases in the future that should make it possible to meet such targets as cutting hunger and poverty in half, slowing the AIDS pandemic, and maintaining needed entitlements.

\section{Production, Consumption, and Technology}

For many, the paradox of sustainable development lies in the need to meet human needs through growing affluence and economy and the threat to the planet that such affluence poses through rapid and growing consumption. There is no generally recognized definition of consumption (30), but we adopt that of the "human transformation of materials and energy (along the productionconsumption chain) ... that makes the transformed materials or energy less available for future use, or negatively impacts biophysical systems in such a way as to threaten human health, welfare, or other things people value" (31). With this definition, major trends related to a sustainability transition are as follows.

Greater Consumption and Less per Unit of Value. The growth in material consumption exceeds the growth in population but is less than the growth in income or value of product. Over the second half of the 20th century, while world population more than doubled, food production almost tripled, energy use more than quadrupled, and the overall level of economic activity quintupled (1). Specific energy fuels or physical materials consumption grow over time as a logistic and decline with substitution. These overall trends differ for the three major development regions. Industrialized countries evidence the greatest decrease in harmful consumption per unit of value of product, but increases in the overall consumption of energy and most materials more than offset such gains. In industrializing countries and urban areas in developing countries, energy and 
materials consumption is growing rapidly with little or no sign of slowing. And for the poorest people and least developed countries, consumption is grossly inadequate, with unmet needs for energy and materials for food production, housing, consumer goods, transportation, and health.

Changing Products and Technologies. The mix of products and the technologies that produce them is changing. Services have grown from $50 \%$ of global gross national product in 1972 to $63 \%$ in 1999 (32), as has the production of information- or knowledge-rich products. Consuming such products and services absorbs affluence but reduces the amount of energy and materials consumed. Economic history finds that industrialized countries regularly replace their lead technologies (33). The emerging technologies of the latest transition include energy sources and transmission, new materials, and the substitution of information for energy and materials, technologies that continue long-term processes of decarbonization, dematerialization, and detoxification.

It is possible to accelerate these long-term processes. To reduce the level of harm per unit of consumption, we can separate more damaging consumption from more benign forms and less damaging and depleting energy and materials for more damaging ones. Beyond substitution, shrinking the energy and material transformations required per unit of consumption is most effective. Addressing the demand side of consumption, it is possible to reduce our consumption by satiation for some goods in high-income countries. An emergent research field $(34,35)$ and a small but growing "simplicity" movement $(36,37)$ grapple with how to encourage consumer behavior that will lead to change in consumption. In rich and poor countries alike, making and selling things to each other, including things we might not need, is the essence of our economic system. Thus, given current trends, it seems quite difficult to move from relatively easy efforts to change technology by substitution and efficiency to changing the making, selling, and desiring of things.

\section{Globalization, Governance, and Institutions}

The very notion of a sustainability transition, with its concern for humankind and the planet, reflects a process of globalization or interconnectedness, emerging forms of governance, and changing institutions and values. Most of these trends will work toward a sustainability transition, but not everywhere. Favorable shifts in investment, income, and job opportunities in some parts of the interconnected world are accompanied by the loss of jobs elsewhere, unpredictable withdrawals of capital, and a deepening divide in needed skills and innovation, all adding new sources of instability for the world's poor. The major trends are as follows.

Deepening Interconnectedness and Persistent Diversity. "In its simplest sense, globalization refers to the widening, deepening, and speeding up of global interconnectedness" (38). Economic production and consumption, migration, communication, and technology all reflect this greater interconnectedness (1). Since 1950, trade has grown at more than twice the rate of economic growth, and current trade in money and capital is 100 times greater than trade in goods and services. Words, images, and ideas outpace the flow of products. The flow of people has also increased and with it the persistence of diversity, particularly in urban areas that attract migrants. This interconnectedness also makes possible the rapid transmission of infectious diseases and invasions of biota. Environmental harms are exported to countries with weaker environmental standards. Concerns about the environment spread, as do increases in consumption fueled by marketing and rapid cultural change. There are also strong countercurrents to global culture that emphasize ethnic, national, and religious distinctiveness, never more evident than on September 11, 2001, when, in the name of religion, the symbolic elements of a globalized economy and military power were targeted.
Widening Governance. Connectedness and diversity are also reflected in institutional innovation and power shifts. At a global level, new institutions of governance have emerged, transnational corporate and financial institutions grow and consolidate, and networks of nongovernmental institutions collaborate and expand. At the subnational level, government has devolved, privatization is common, and civic society in many places has been strengthened. Power has shifted from the national state upward to the global level and downward to the local level, and at all levels from the public to the private $(39,40)$. Again, the events of September 11, 2001, illustrate how great military power could shift to a shadowy nongovernmental organization.

Changing Values. The last 50 years have also seen extraordinary changes in values, attitudes, and actual behavior. The World Values Surveys have marked a generational transition from "traditional" to "modern" and most recently "postmodern" values that include the values underlying the great attitudinal and behavioral shifts in sex and reproduction, the role of women, the environment, and human rights. Economic development tends to push societies in this common direction, but societal values, rather than converging, seem to move on parallel tracks distinctly shaped by their cultural heritages (41).

In general, there seems to be little opportunity to change the major directions in trends of globalization of increasing interconnectedness, persistent diversity, and shifts in power between public and private, local and global. Indeed, the very notion of "sustainable development" is a product of the interconnectedness that characterizes globalization. But if the goods of globalization are to be realized and its ills are to be reduced for those people and natural systems most vulnerable, then globalization itself must change in some significant way. In similar historic periods of national and continental transformation, needed changes emerged that suggest parallels for today. Early regulatory effort was needed around what today are called "rule of law" and "transparency" issues, such as those that make contracts enforceable or stock certificates verifiable. These efforts were followed by various attempts to control monopoly power and maintain genuine competitiveness. Much slower were those efforts that recognized the victims, harms, inequities, and externalities generated by the new integrated industrial system. Last were efforts to reduce environmental harm. The challenge for humanizing globalization is to reduce the duration of this century-long precedent by half, thus controlling the extremes of economic power, assisting victims of change, and protecting the environment in no more than two generations (42).

\section{Global Environmental Change}

Preserving the life support systems of the planet is made more difficult by the rapid and continuing global environmental changes in the air, oceans, land, and freshwater systems. Because most of these are linked to human actions, including actions to meet human needs, slowing, stabilizing, or reversing such change takes on great urgency for a sustainability transition.

Rapid Environmental Change and Changing Problems. Local, regional, and global environmental change by humans has been underway for at least the past 10,000 years, but most of that change has occurred over the last half-century (43). The atmosphere and oceans, land and freshwaters, species, ecosystems, and living resources, and the great biogeochemical and hydrological cycles have been fundamentally altered. Flows of materials and energy that are removed from their natural settings or synthesized now rival the flows of such materials within nature itself. Overall estimates of the human modification, management, or appropriation of nature range up to one-half of the terrestrial ecosystems (44) and onequarter of the freshwater supply (45).

For humankind, the dominant environmental problems related 
to such rapid change seem to vary regionally and are related to per capita income (46). For people resident in the poorest nations and the poorest sections of large cities in industrializing nations, the dominant problems are often public health problems of lack of clean water and sanitation and indoor air pollution. As income increases and many of these problems are rectified by indoor plumbing and vented cook stoves, outdoor air and water pollution become the characteristic problems of cities and watersheds. For the richest countries, there is substantial reduction in local air and water pollution but an increase in transboundary air and water problems and the emergence of global-scale problems such as climate change.

Somewhat different strategies are called for to accelerate action on the dominant environmental problems. Targets for cutting in half the numbers of people without access to clean water and sanitation are realizable with fulfillment of pledges made for additional funding, because the needed technologies have not really changed in over half a century. In contrast, accelerating action on the air and water pollution of the newly industrializing nations requires leapfrogging the slow path of growing regulation and technology substitution followed by the industrialized countries. Most difficult of all will be addressing climate change for lack not of technological and social innovations but of universal agreement as to need, urgency, and shared responsibility.

Atmosphere. The atmosphere provides the air we breath and protection from harmful solar radiation and is a major regulator of the climate system we depend on for suitable habitat. Major atmospheric trends include the following.

Decreasing and increasing air pollutants. Major air pollutants have a significant impact on human health, ecosystems, and agricultural productivity. By 1990 , global $\mathrm{SO}_{\mathrm{x}}$ emissions increased a factor of $>5.5$ from their levels in 1900 (47). However, they appear to have peaked in 1989 and declined by $2.6 \%$ by 2000 (48). In industrialized countries, tropospheric air pollution has been significantly reduced, as in the U.S., where nationally averaged concentrations of nitrogen dioxide, ozone, sulfur dioxide, carbon monoxide, and lead have respectively declined. Although rapidly industrializing countries such as China and South Korea have been recently successful in reducing emissions of some pollutants (e.g., $\mathrm{SO}_{\mathrm{x}}$ ), emissions of others (e.g., $\mathrm{NO}_{\mathrm{x}}$, nonmethane volatile organic compounds) continue to grow rapidly $(14,49-51)$.

Declining but stabilizing stratospheric ozone. The ozone layer in the stratosphere serves to screen solar UV radiation that is harmful to all forms of life. Beginning in the 1930s, human use of chlorofluorocarbon gases for refrigerants, solvents, and other useful products have released these chemicals into the upper atmosphere, where they interact to destroy ozone. The effect was discovered in the early 1970 s (52) and dramatized a decade later by the discovery of the Antarctic seasonal ozone hole $(53)$ and its causes $(54,55)$, which led in turn to a treaty to reduce chlorofluorocarbon emissions in 1987 (56). As a result, the ozone layer is projected to stabilize in the next decade or two (57).

Increasing concentrations of "greenhouse" gases and global warming. Carbon dioxide is the major radiatively active greenhouse gas. The carbon dioxide content of the atmosphere has increased $\approx 85$ parts per million since 1750 , and the earth has warmed $0.6 \pm 0.2^{\circ} \mathrm{C}$ since 1861. Globally, the last decade has been the warmest since records began in 1861. In the Northern Hemisphere, the last century was the warmest in the last 1,000 years (58). Global carbon emissions from the consumption and flaring of fossil fuels were $8.3 \%$ greater in 2000 than in 1990 (59). Even if emissions are stabilized at levels below those of 1990 for industrialized countries, as required by the Kyoto Protocol, emissions and warming will continue to grow. Impacts from warming on ecosystems and biota are increasingly evident, especially in arctic and mountainous areas.

Future air pollutants and greenhouse gas emissions will depend on the complex interactions between population growth, economic growth, and technological innovation. We have addressed opportunities for favorably influencing population and consumption above and described prospects for accelerating favorable trends in the previous section.

Oceans. Oceans are vital to human well-being. Fish provide an important source of nourishment, currents play a major role in shaping habitable climate for much of the world, and the ocean surface is a conduit for global commerce. Coastal zones, estuaries, and confined seas are intensively used, because they give access to different sets of resources: port location, recreation, tourism, and, aquaculture. Major oceanic trends include the following.

Warming oceans and degrading coastal zones. Because of their enormous size, the chemical composition of the open oceans, with the exception of lead, has not been greatly affected by human activities (60). However, the oceans have warmed, and this is a major factor in the observed sea level rise of $10-20 \mathrm{~cm}$ over the last century. There is also a small probability that continued warming will significantly alter the existing system of ocean currents (58). In 1994, $\approx 44 \%$ of Earth's population lived within $200 \mathrm{~km}$ of a coastline (61), a number that has grown over time. Much of their waste, garbage, and waterborne pollutants, as well as ship-borne waste, oil spills, and distant agricultural runoff, end up offshore. These trends will likely intensify as populations along the coast grow; coastal transport, recreation, and aquaculture increase; and global warming and rising sea level increase.

Decreasing ocean fisheries. Despite strong international consensus to preserve maximum sustainable yields, commercial fisheries are significantly more stressed today than 30 years ago (62). The percentage of stocks being fished beyond maximum sustainable yield has nearly tripled from $10 \%$ in 1970 to $28 \%$ in 1999 , and $75 \%$ of all stocks are either overfished or at capacity. For those fish that require freshwater in their life cycle, habitat degradation adds further stress, as does widespread coral bleaching and direct destruction of the coral reefs for reef-based fish (63).

The opportunities to favorably alter the trend toward continued sea-level rise are coupled to those for controlling atmospheric concentrations of greenhouse gases. With advance knowledge that a future rise is likely, there are opportunities to reduce human consequences by limiting further development in vulnerable areas and reinforcing or relocating existing infrastructure. Opportunities for restoring the health of ocean fisheries include reducing pollution, adoption of lesser-impact fishing practices, and the protection/ restoration of critical coastal habitats.

Land. ${ }^{\S}$ Of the human-induced impacts on the biosphere, land cover change is the most ancient, the first to obtain a "global" magnitude, and pivotal to virtually every facet of contemporary globalenvironmental change, from biogeochemical cycling to ecosystem health (65-71). The most dramatic conversion of land from natural resource use to urban has profound local and regional impacts but small cumulative change at global scale. More global are trends related to forest-woodland, agriculture, and grassland-pasture. Decreasing tropical and increasing temperate and boreal forests. Despite the loss of $\approx 47 \%$ of the world's forests historically to domestication, they occupy about one-fourth of the world's ice-free land area (66, $67)$, with over one-half located in the tropics. Tropical forests declined at an estimated rate of 12.3-14.2 million hectares per annum from 1990 to $2000^{\mathbb{I}}$ (68) and modification of remaining or regenerating forests through short-to-medium successional growth, landscape fragmentation, and understory burning $(69,70)$. Temperate and boreal forests are reforesting as the economics of land use shift the value of more marginal agricultural lands in favor of

5This section draws extensively on ref. 64 .

กThe lower estimate includes plantation forests, and the upper estimate considers only natural forests. 
periurban, recreational, and preservation-conservation uses and through more rapid growth from increased carbon dioxide and global warming (71-82). But one major exception relates to the former command economies, particularly Siberia, where deforestation is significant and occurring at high rates $(72,73)$.

Intensification and expansion in cultivated lands. A very long-term trend finds intensified production on prime croplands in industrialized and industrializing economies predicated on high inputs of water, fertilizer, pesticides, and improved seeds, although limits to yield increases are now becoming apparent. Less developed economies tend to have both high-input (often irrigated) systems and lower-input systems with increasing competition between commercial production and the subsistence agriculture essential to household needs, especially in subSaharan Africa $(74,75)$. Thus sustained expansion of croplands will take place in developing economies, especially the tropics, arid and semiarid lands, and high mountains (43). These lands situated in the tropics are precisely those most susceptible to climate warming (76), and those also arid may suffer from significant water shortages (43).

Modification of grasslands and pasturelands. Trends for grasslands and pasturelands are poorly understood and are caught up in the "desertification" theme that has overestimated human degradation of arid lands globally and in specific cases, such as the expansion of the Sahara $(77,78)$. "Systematic" assessments providing estimates of grassland change have too large a variance to be helpful (79), but agreement exists that grasslands have been extensively modified worldwide, perhaps increasingly degraded in terms of standing biomass $(80,81)$. Pasturelands will continue to expand in Latin America, although much of the areas transformed to pasture will revert back to other land covers. Small areas of abandoned cultivation have reverted to grasslands in the southern Great Plains of the U.S. (82).

Decreasing biological diversity and increasing biological invasions. Directly related to the rapid land changes is the decreasing diversity through either species extinction or species reduction in managed agroforestry systems. Recent extinction rates are $100-1,000 \times$ their prehuman levels (83). At present, $11 \%$ of bird species, close to $18 \%$ of mammals, $\approx 8 \%$ of plant species, and $5 \%$ of fish species are currently threatened $(44,84)$. In areas where studies have been carried out, $\approx 20 \%$ of freshwater species are threatened, endangered, or extinct (62). Overfishing, dam building, irrigation, and urban, agricultural, and industrial contamination have turned great lakes into wastelands. In a globalized world, biological invasions have grown. Exotic species have increased diversity in some places and decreased it elsewhere as immigrant species replace local ones (85).

Absent unlikely changes in the global political economy, the land trends noted here appear hard to abate in the near future, if only because so many of the changes underway take place in conditions in which the human agents of change have few choices. One current trend that should continue is agricultural intensification on prime lands to allow marginal lands to revert back to tree or grass cover. Favorably influencing the long-term trends of declining biodiversity will require new approaches to land management. Past practices of preserving specific species or land areas will have to be augmented to address ecosystems as a whole, including their human inhabitants. These efforts may include the creation of corridors that connect pieces of fragmented habitats, creating low-impact livelihoods for residents and establishing demand for lesser-impact crops. Prevention is the best approach toward the control of invasive species. However, this task has become much more difficult in the face of rapidly growing global commerce and travel.

Freshwater. Freshwater is one of the fundamental building blocks of life. Continued access to freshwater is required for drinking water, agricultural production, and industrial processes.
Growing but slowing water withdrawals. "Global withdrawals of water to satisfy demands have grown dramatically in this century. Between 1900 and 1995, water withdrawals increased by over six times, more than double the rate of population growth. This rapid growth in water demand is due to the increasing reliance on irrigation to achieve food security, the growth of industrial uses, and the increasing use per capita for domestic purposes" (86). However, per capita withdrawals peaked in the mid-1980s. Since then, per capita water withdrawals have declined and absolute water withdrawals have slowed worldwide (87). In industrialized countries, competing needs for urban, industrial, and agricultural use have encouraged greater efficiency of use, leading to reduced per capita consumption. In the U.S., for example, per capita water withdrawal declined by $22 \%$ between 1980 (its peak) and 1995 (88).

Growing regional and local scarcity. Although freshwater is widely available, it is unevenly distributed. Many places in the world suffer local shortages, and water stress is widespread in one-third of the world, where withdrawals exceed $20 \%$ of available supply (86). In many places, the quality of available water continues to decline because of pollution and salinization. Most significant is the unmet need for household water use, with 1.2 billion people in developing countries lacking access to a safe and reliable supply and 2 billion lacking access to sanitation.

Agriculture, primarily irrigation, accounts for $70 \%$ of current freshwater withdrawals (86). This suggests that the largest opportunity for accelerating the trend in reducing freshwater withdrawals is through greater efficiency in agricultural production. For industrializing countries in arid regions, there are major opportunities to reduce industrial and residential consumption by reducing losses and improving technology (86).

\section{Conclusion}

Despite United Nations Secretary-General Kofi Annan's words, "[t]he summit makes sustainable development a reality," the recently concluded World Summit for Sustainable Development made at best modest contributions to a sustainability transition. There should be little doubt that such a 2050 transition that met the needs of a much larger population while preserving the planet's life support systems is possible $(1,5)$. Nonetheless, a global transition is in doubt because of the long-term trends described in this article, some of which make a transition more likely and others that make it less so. Indeed, each of the major classes of trends are comprised of a collection of multitrends, containing in essence both the "good news" and "bad news" for the future of a transition. Many of the differences in trends are expressed spatially, with different regions experiencing the good news or the bad news.

In our judgment, if the mix of favorable and unfavorable trends continues at the current pace, it is unlikely that a 2050 transition will be realized. The current pace of meeting such human needs as feeding, nurturing, educating, housing, and employing the growing population, while improving, is well behind the pace needed to realize such international targets as halving the number of hungry or providing clean water and sanitation (20). At the same time, the absolute growth in threats to the life support systems from the world's production and consumption systems still exceeds the pace of the countering trends in reducing energy and material use, in reducing pollutants, and in controlling the unsustainable extraction of land and sea resources.

Thus a central task of sustainable development will be to accelerate the trends that favor a transition and slow the trends that impede them. The trends described in this paper can provide a checklist for a continuing assessment of the major forces affecting a sustainability transition. Because sustainable development takes place locally rather than globally, an important task for a placebased sustainability science is to identify the specific trends most relevant to such places and the ways in which local populations can contribute to altering the trends that affect them (89). 
It is also characteristic of much current debate to selectively choose those trends supportive of particular positions and ignore contradictory trends. Thus, some analysts choose to emphasize either growing populations or slowing population growth, growing energy and material consumption, or declining energy and material use per unit of value, growing incomes or growing inequality of incomes; yet all these trends are significant. Given the tendency of participants in contentious public dialogues to selectively note only the specific trends that support their point of view, it is the responsibility of sustainability science to map the broad, inclusive,

1. National Research Council (1999) Our Common Journey (Natl. Acad. Press, Washington, DC)

2. Raskin, P., Gallopin, G., Gutman, P., Hammond, A. \& Stewart, R. (1998) Bending the Curve (Stockholm Environmental Inst., Boston)

3. Kates, R. W., Clark, W. C., Corell, R., Hall, J. M., Jaeger, C. C., Lowe, I., McCarthy, J. J., Schellnhuber, H. J., Bolin, B., Dickson, N. M., et al. (2001) Science 292, 641-642. 4. Kates, R. W. (2001) Forum on Science and Technology for Sustainability (http:// sustainabilityscience.org)

5. Raskin, P., Banuri, T., Gallopín, G., Gutman, P., Kates, R. \& Swart, R. (2002) Great Transition (Stockholm Environmental Inst., Boston).

6. Gurr, T. R., Marshall, M. G. \& Khosla, D. (2001) Peace and Conflict 2001 (Center for International Development and Conflict Management, College Park, MD).

7. Sarkees, M. R. (2000) Conflict Management and Peace Science 18, 123-144.

8. Drumtra, J. (2001) Refugee Rep. 22, 1-7.

9. Kaplan, R. D. (1994) Atlantic Monthly 273, 44-76

10. Huntington, S. P. (1993) Foreign Affairs 72, 22-49.

11. Sollenberg, M. \& Wallensteen, P. (2001) in SIPRI Yearbook 2001 (Oxford Univ. Press, Oxford)

12. Lash, J. (2001) Science 294, 1789.

13. Folke, C., Jansson, A., Larsson, J. \& Costanza, R. (1997) Ambio 26, 167-172.

14. Chameides, W. L., Kasibhatla, P. S., Yienger, J. \& Levy, H. (1994) Science 264, 74-77.

15. United Nations Population Division (2003) World Population Prospects (United Nations, New York), ESA/P/WP, 180.

16. United Nations Population Division (2002) World Urbanization Prospects the 2001 Revision (United Nations, New York).

17. Bongaarts, J. \& Bruce, J. (2001) in The Unfinished Agenda, eds. Pinstrup-Andersen, P. \& Pandya-Lorch, R. (Internat. Food Policy Research Inst., Washington, DC).

18. Ausubel, J. H. \& Herman, R. (1988) Cities and Their Vital Systems (Natl. Acad. Press, Washington, DC)

19. United Nations Development Programme (2002) Human Development Report 2002 (United Nations Development Programme, New York)

20. Parris, T. M. \& Kates, R. W. (2003) Proc. Natl. Acad. Sci. USA 100, 8068-8073.

21. Maddison, A. (2001) The World Economy (Organisation for Economic Cooperation and Development, Paris)

22. World Bank (2001) Global Economic Prospects and the Developing Countries 2001 (International Bank for Reconstruction and Development, Washington, DC)

23. United Nations Development Programme (1996) Human Development Report 1996 (Oxford Univ, Press, New York)

24. Galbraith J. K. \& Berner, M. (2001) Inequality and Industrial Change (Cambridge Univ, Press, New York)

25. Baumol, W. J., Nelson, R. R. \& Wolff, E. N. (1994) Convergence of Productivity (Oxford Univ. Press, New York).

26. Sen, A. K. (1982) Poverty and Famines (Oxford Univ, Press, New Delhi).

27. World Bank (2000) World Development Indicators 2000 (International Bank for Reconstruction and Development, Washington, DC)

28. World Resources Institute (2000) World Resources 2000-2001 (World Resources Inst., Washington, DC)

29. Barrett, R., Kuzawa, C. W., McDade, T. \& Armelagos, G. J. (1998) Annu. Rev Anthropol. 27, 247-271.

30. Stern, P. C., Dietz, T., Ruttan, V., Socolow, R. H. \& Sweeney, J. L. (1997) Environmentally Significant Consumption (Natl. Acad. Press, Washington, DC)

31. Royal Society of London and U.S. National Academy of Sciences (1977) Popul. Dev. Rev. 23, 68386

32. World Bank (2002) World Development Indicators 2002 (International Bank for Reconstruction and Development, Washington, DC).

33. Grübler, A. \& Nowtony, H. (1990) Int. J. Technol. Manage. 5, 431-471.

34. Jager, W., van Asselt, M., Rotmans, J., Vlek, C. \& Costerman Boodt, P. (1997) Consumer Behavior (Natl. Inst. for Public Health and the Environment, Bilthoven, The Netherlands), Rep. 461502017

35. Vellinga, P., de Bryn, S., Heintz, R. \& Mulder, P. (1997) Industrial Transformation (Inst. for Environmental Studies, Amsterdam), IHDP-IT, no. 8

36. Nearing, H. \& Nearing, S. (1990) The Good Life (Schocken, New York)

37. Elgin, D. (1993) Voluntary Simplicity (William Morrow, New York)

38. Held, D. (1999) Global Transformations (Stanford Univ. Press, Stanford, CA).

39. Mathews, J. T. (1997) For. Aff. 76, 50-66.

40. Clark, W. C. (2001) Ecol. Law Q. 27, 1021-1075.

41. Inglehart, R. \& Baker, W. E. (2000) Am. Soc. Rev. 65, 19-51.

42. Kates, R.W. (2003) in Worlds Apart: Globalization and the Environment, ed. Speth, G. J. (Island, Washington, DC), pp. 85-107.

43. Turner, B. L., II, Clark, W. C., Kates, R. W., Richards, J. F., Mathews, J. T. \& Meyer, W. B. (1990) The Earth as Transformed by Human Action (Cambridge Univ. Press, Cambridge, U.K.

44. Vitousek, P. M., Mooney, H. A., Lubchenco, J. \& Melillo, J. M. (1997) Science 277, 494-499.

45. Postel, S. L., Daily, G. C. \& Ehrlich, P. M. (1996) Science 271, 785-788. and contradictory currents that humankind will need to navigate toward a just and sustainable future.

We thank B. L. Turner II and Alex Pulsipher for extensive analysis of land use and cover change and our other colleagues in the Research and Assessment Systems for Sustainability Program (http://sust.harvard. edu) for encouragement and constructive criticism of earlier drafts. This paper is based on research supported in part by a grant from the National Science Foundation (Award BCS-0004236), with contributions from the National Oceanic and Atmospheric Administration's Office of Global Programs for the Research and Assessment Systems for Sustainability Program, and ISciences, LLC.

46. World Bank (1992) World Development Report 1992 (International Bank for Reconstruction and Development, Washington, DC)

47. Lefohn, A. S., Husar, J. D. \& Husar, R. (1999) Atmos, Environ. 33, 3435-3444

48. Intergovernmental Panel on Climate Change (2000) Special Report on Emission Scenarios (Cambridge Univ. Press, Cambridge, U.K.)

49. Streets, D. G., Tsai, N. Y., Akimoto, H. \& Oka, K. (2000) Atmos. Environ. 34, 4413-4424

50. Streets, D. G., Tsai, N. Y., Akimoto, H. \& Oka, K. (2001) Water Air Soil Poll. 130, 187-192

51. Klimont, Z., Streets, D. G., Gupta, S., Cofala, J., Fu, L. X. \& Ichikawa, Y. (2002) Atmos Environ. 36, 1309-1322.

52. Molina, M. J. \& Rowland, F. S. (1974) Nature 249, 810-812.

53. Farman, J. C., Murgatroyd, R. J., Silnickas, A. M. \& Thrush, B. A. (1985) Q. J. R. Meteor. Soc. 111, 1013-1025.

54. Crutzen, P. J. \& Arnold, F. (1986) Nature 324, 651-655.

55. Anderson, J. G., Brune, W. H. \& Proffitt, M. H. (1989) J. Geophys. Res. Atmos. 94, $11465-11479$.

56. Benedick, R. E. (1991) Ozone Diplomacy (Harvard Univ, Press, Cambridge, MA)

57. World Meteorological Organization (1998) Scientific Assessment of Ozone Depletion 1998 (World Meteorological Organization, Geneva)

58. Intergovernmental Panel on Climate Change (2001) Technical Summary: A Report of Working Group I of the Intergovernmental Panel on Climate Change (Intergovernmental Panel on Climate Change, Geneva).

59. Energy Information Agency (2002) International Energy Annual 2000 (U.S. Dept. o Energy, Washington, DC), Appendix H.

60. Jickells, T. D., Carpenter, R. \& Liss, P. S. (1990) in The Earth As Transformed by Human Action, eds. Turner, B. L., II, Clark, W. C., Kates, R. W., Richards, J. F., Mathews, J. T. \& Meyer, W. B. (Cambridge Univ. Press, Cambridge, U.K.)

61. Cohen, J. E., Small, C., Mellinger, A., Gallup, J. \& Sachs, J. (1997) Science 278, 1209-1213.

62. Food and Agriculture Organization (2000) The State of World Fisheries and Aquaculture (Food and Agriculture Organization, Rome)

63. Hinrichsen, D. (1997) Bioscience 47, 554-558.

64. Turner, B. L., II (2002) in Challenges of a Changing Earth: Proceedings of the Globol Change Open Science Conference, eds. Steffen, W., Jäger, J., Carson, D. \& Bradshaw, C. (Springer, Heidelberg), pp. 21-26.

65. Alroy, J. (2001) Science 292, 1893-1896.

66. Imhoff, M. L. (1994) Bioscience 44, 598-598.

67. World Resources Institute (1998) World Resources 1998-1999 (Oxford Univ. Press, Oxford).

68. Food and Agriculture Organization (2001) State of the World's Forests 2001 (FAO, Rome).

69. Moran, E. F., Brondizio, E. S., Tucker, J. M., da Silva-Forsberg, M. C., McCracken, S. \& Falesi, I. (2000) For. Ecol. Manage. 139, 93-108

70. Skole, D. \& Tucker, C. (1993) Science 44, 314-322.

71. Tri-Academy Committee (2001) Growing Populations, Changing Landscapes (Natl Acad. Press, Washington, DC).

72. Aksenov, D., Dobrynin, D., Dubinin, M., Egorov, A., Isaev, A., Karpachevskiy, M. Laestadius, L., Potapov, P., Purekhovskiy, A., Turubanova, S. \& Yaroshenko, A. (2002) Atlas of Russia's Intact Forest Landscapes (Russian Nongovernmental Organizations Forest Club, Moscow)

73. Bartalev, S., Achard, F., Erchov, D. \& Gond, V. (2000) in Vegetation 2000 Conference Proceedings, ed. Saint, G. (Joint Research Center, Ispra, Italy), pp. 127-142

74. Ruttan, V. W. (2002) J. Econ. Perspect. 16, 161-184.

75. Turner, B. L., II, Hyden, G. \& Kates, R. W., eds. (1993) Population Growth and Agricultural Change in Africa (Univ. Press of Florida, Gainesville).

76. Rosenzweig, C. \& Hillel, D. (1998) Climate Change and the Global Harvest (Oxford Univ Press, New York)

77. Johnson, D. L. \& Lewis, L. A. (1995) Land Degradation (Blackwell, Oxford).

78. Thomas, D. S. G. (1997) J. Arid Environ. 37, 599-608

79. Klein Goldewijk, K. (2001) Global Biogeochem. Cycles 15, 417-433.

80. Behnke, R., Scoones, I. \& Kerven, C. (1993) Range Ecology at Disequilibrium (Overseas Development Inst., London).

81. Chapman, G. P., ed. (1992) Desertified Grasslands (Academic, London)

82. Brooks, E. \& Emel, J. (2000) The Llano Estacado of the US Southern High Plains (United Nations Univ. Press, Tokyo).

83. Pimm, S. L., Russell, G. J., Gittleman, J. L. \& Brooks, M. (1995) Science 269, 347-350

84. Chapin, F. S., III (2000) Nature 405, 234-242.

85. Mooney, H. A. \& Cleland, E. E. (2001) Proc. Natl. Acad. Sci. USA 98, 5446-5451.

86. Commission on Sustainable Development (1997) Comprehensive Assessment of the Freshwater Resources of the World (United Nations, New York), E/CN 17/1997/9.

87. Gleick, P. H. (2000) The World's Water 1998-1999 (Island, Washington, DC)

88. Solley, W. B., Pierce, R. R. \& Perlman, H. A. (1998) Estimated Use of Water in the United States in 1995 (U.S. Geological Survey, Washington, DC), Circular 1200.

89. Association of American Geographers Global Change and Local Places Research Group (2002) Global Change in Local Places (Cambridge Univ. Press, Cambridge, U.K.) 